\title{
Review \\ Prognostic molecular markers in early breast cancer
}

\section{Francisco J Esteva ${ }^{1,2}$ and Gabriel N Hortobagyi ${ }^{1}$}

\author{
1'Department of Breast Medical Oncology, The University of Texas MD Anderson Cancer Center, Houston, Texas, USA \\ 2Department of Molecular \& Cellular Oncology, The University of Texas MD Anderson Cancer Center, Houston, Texas, USA
}

Corresponding author: Francisco J Esteva (e-mail: festeva@mdanderson.org)

Published: 11 March 2004

Breast Cancer Res 2004, 6:109-118 (DOI 10.1186/bcr777)

(C) 2004 BioMed Central Ltd

\begin{abstract}
A multitude of molecules involved in breast cancer biology have been studied as potential prognostic markers. In the present review we discuss the role of established molecular markers, as well as potential applications of emerging new technologies. Those molecules used routinely to make treatment decisions in patients with early-stage breast cancer include markers of proliferation (e.g. Ki67 ), hormone receptors, and the human epidermal growth factor receptor 2 . Tumor markers shown to have prognostic value but not used routinely include cyclin $D_{1}$ and cyclin $E$, urokinase-like plasminogen activator/plasminogen activator inhibitor, and cathepsin D. The level of evidence for other molecular markers is lower, in part because most studies were retrospective and not adequately powered, making their findings unsuitable for choosing treatments for individual patients. Gene microarrays have been successfuly used to classify breast cancers into subtypes with specific gene expression profiles and to evaluate prognosis. RT-PCR has also been used to evaluate expression of multiple genes in archival tissue. Proteomics technologies are in development.
\end{abstract}

Keywords: biological tumor markers, breast cancer, genomics, prognosis, proteomics

\section{Introduction}

Breast cancer is the most common malignancy in women, and it is highly curable if diagnosed at an early stage. Traditional prognostic factors include the axillary lymph node status, the tumor size, and the nuclear grade and histologic grade. Interest in novel prognostic markers is based on the fact that a significant number of patients with early-stage breast cancer harbor microscopic metastasis at the time of diagnosis. It is now well established that adjuvant systemic therapy improves survival in patients with early-stage breast cancer $[1,2]$. Treatment options for early-stage breast cancer include chemotherapy (e.g. anthracyclines, taxanes) and hormone therapy (e.g. tamoxifen, aromatase inhibitors). The use of trastuzumab is under investigation in the adjuvant setting for patients with human epidermal growth factor receptor (HER) 2 overexpressing breast cancer.
Systemic therapies are potentially toxic, however, and identifying the individual patients who are at high risk and likely to benefit remains a major challenge. For example, the risk of recurrence for a patient with negative axillary lymph nodes and a tumor measuring $1-2 \mathrm{~cm}$ is approximately 20-30\%. Most patients in this group are currently offered adjuvant systemic therapy, although up to $70 \%$ of patients would not need it because they are already cured of their disease. Unfortunately, the histologic information is clearly not sufficient to accurately assess individual risk and to possibly avoid adjuvant systemic therapy. A large number of molecular markers have been studied to determine their ability to predict prognosis or response to therapy, or both (Table 1). Prognostic factors correlate with survival independent of systemic therapy, and are used to select patients at risk. Predictive factors correlate response to therapy independent of prognosis, and have a

DFS = disease-free survival; ELISA = enzyme-linked immunosorbent assay; ER = estrogen receptor; HER = human epidermal growth factor receptor; $\mathrm{IHC}=$ immunohistochemistry; PAI = plasminogen activator inhibitor; PCR = polymerase chain reaction; $\mathrm{PR}=$ progesterone receptor; RT $=$ reverse transcription; $\mathrm{uPA}=$ urokinase-type plasminogen activator. 
Table 1

\begin{tabular}{ll}
$\begin{array}{l}\text { Well-established and investigational prognostic factors in } \\
\text { breast cancer }\end{array}$ \\
\hline $\begin{array}{l}\text { Well-established } \\
\text { prognostic factor }\end{array}$ & $\begin{array}{l}\text { Investigational } \\
\text { prognostic factor }\end{array}$ \\
\hline Ki-67 & pS2 \\
Estrogen receptor & Mitosin \\
Progesterone receptor & Epidermal growth factor receptor \\
HER-2 & Insulin-like growth factors \\
& Apoptosis-related proteins \\
& Cell cycle molecules \\
& Plasminogen activators and inhibitors \\
& Angiogenesis-related proteins \\
\hline
\end{tabular}

significant impact in selected patient populations. Some molecular markers are associated with prognosis, some are associated with response to therapy, and some are associated with both.

Although a large number of molecules have been investigated as potential prognostic and predictive factors, the National Institute of Health Consensus Development Conference held in 2000 stressed the need for validation and appropriate quality control for most of the markers studied to date [3]. The present article reviews the available data on established and investigational prognostic molecular markers in patients with early-stage breast cancer.

\section{Proliferation markers}

The tumor proliferation rate is an important prognostic factor in breast cancer. Several methods have been developed to estimate the proliferative rate of tumor cells. The S-phase fraction, as measured by flow cytometry, is a validated method for measuring tumor proliferation [4]. However, flow cytometry is not commonly used because of the amount of tissue consumed for the assay. Alternative methods for measuring tumor proliferation have been developed, including immunohistochemistry (IHC) to detect cell cycle-related antigens, that are better suited for the evaluation of small archival tissue samples.

$\mathrm{Ki}-67$ is a nuclear antigen found in cells in the proliferative phases of the cell cycle (G1 phase, S phase, G2 phase, and $M$ phase) but not cells in the resting phase (GO phase). MIB-1 is a monoclonal antibody that identifies the $\mathrm{Ki}-67$ protein in paraffin-embedded tissue. A strong correlation has been noted between the percentage of cells showing Ki-67 staining and the nuclear grade, age, and mitotic rate $[5,6]$. Patients whose tumors overexpress $\mathrm{Ki}-67$ in more than $50 \%$ of the cells are at high risk of correlates with other well-characterized proliferation markers, such as the proliferating cell nuclear antigen [6].

Mitosin, a recently described 350-kDa nuclear phosphoprotein, is expressed in the late $\mathrm{G} 1$ phase, $\mathrm{S}$ phase, $\mathrm{G} 2$ phase, and $M$ phase of the cell cycle, but not in the G0 phase [8]. Clark and colleagues [9] showed that mitosin is a proliferation marker that correlates with high S-phase fraction and negative estrogen receptor (ER)/progesterone receptor (PR) status. Although mitosin was not a predictor of survival in the study by Clark and colleagues, it was an independent predictor of recurrence. Additional studies are necessary to validate these findings.

\section{Estrogen receptors and progesterone receptors}

Estrogen mediates its functions through two specific intracellular receptors, the ER $\alpha$ and the ER $\beta$, which act as hormone-dependent transcriptional regulators [10,11]. The ER pathway plays a critical role in the pathophysiology of human breast cancer. Overexpression of $E R \alpha$ is a well-established prognostic and predictive factor in breast cancer patients. The prognostic significance of ER $\beta$ is not well defined [12-15]. Overexpression of the PR serves as a functional assay because it indicates that the ER pathway is intact, even if the tumor is reported as ER-negative. When biochemical ligand-binding assays indicate concentrations of $10 \mathrm{fmol} / \mathrm{mg}$ cytosol protein or more, the tumors are generally considered ER-positive and PR-positive for clinical purposes.

The ER and PR status can be measured using IHC. The results of IHC correlate closely with biochemical ligandbinding assays and with clinical response rates to endocrine therapy [16]. Because IHC, unlike chemical assays, does not require the destruction of tissue specimens, and because it shows the tissue distribution of ER, it has become the preferred method for determining the ER/PR status in breast cancer specimens. Quantitative methods using computer-aided image analysis are being developed to improve the accuracy of IHC.

The value of ER status as an independent prognostic variable is diminished by its association with other established indicators of favorable prognosis. These include older age, low-grade histology, a favorable nuclear grade, a low S-phase fraction, a normal complement of DNA, a low proliferative index, and a low thymidinelabeling index [17]. In addition, ER-positive patients receive and benefit from either adjuvant or palliative hormone therapy so regularly that it is difficult to evaluate the prognosis apart from the influence of therapy.

In some studies, the higher disease-free survival (DFS) and overall survival rates of patients with ER-positive tumors are seen only in the presence of hormone therapy. Often the favorable effect of ER-positive status as a 
discriminant is lost after several years, suggesting that the influence of treatment is temporary $[18,19]$. When nodepositive patients not receiving adjuvant hormone therapy were studied, the 5-year DFS rate was 20\% higher for ERpositive patients compared with that for ER-negative patients. However, the 5-year DFS rate of the most favorable subgroup (i.e. patients with one to three positive nodes and ER-positive tumors) did not exceed 60\% [20].

Among node-negative patients, small but statistically significant differences in DFS and overall survival rates have been found between ER-positive cases and ERnegative cases after various periods of follow-up [21]. The results of a multivariate analysis of prognostic factors by McGuire and colleagues [22], including the ER status for more than 3000 patients, showed the ER status to be more important for prognosis than tumor size in nodenegative cases but not in node-positive cases. In one study, the ER status was found to be less important for predicting duration of DFS or overall survival than the nuclear grade and the number of positive nodes [23]. Allred and colleagues [24] showed that tamoxifen decreased the risk of local-regional recurrence in patients with ER-positive ductal carcinoma in situ.

The ER IHC assay is not standardized. Methods of tissue procurement, preservation, antigen retrieval, and, more importantly, the definition of positivity vary between different laboratories.

The prognostic role of ER $\beta$ is not well defined. Fuqua and colleagues [25] evaluated ER $\beta$ expression using IHC in 242 breast cancer patients. Their study showed that most tumors coexpressed both ER $\alpha$ and ER $\beta$. Although ER $\alpha$ expression was positively correlated with low tumor grade, with diploidy, and with low S-phase fraction (all biological parameters of a good prognostic profile), ER $\beta$ trended toward an association only with aneuploidy. No association with tumor grade or S-phase fraction was seen for ER $\beta$. Larger studies are needed to determine the clinical utility of ER $\beta$ expression in breast cancer.

\section{Human epidermal growth factor receptor 2}

The most frequently implicated receptors and growth factors in human breast cancer are members of the epidermal growth factor receptor subfamily of tyrosine kinase receptors. In addition to epidermal growth factor receptor, the type I subfamily includes HER-2, HER-3, and HER-4 $[26,27]$. These receptors share a common molecular architecture; they all possess a large glycosylated extracellular ligand-binding domain, a single hydrophobic transmembrane domain, and a cytoplasmic tyrosine kinase domain.

HER-2 (also known as c-erbB-2 or neu) is a proto-oncogene that encodes a $185-\mathrm{kDa}$ tyrosine kinase glycoprotein.
Amplification of the HER-2 gene plays an important role in the pathogenesis of breast cancer [28-30]. The HER-2 protein is overexpressed in $60 \%$ of ductal carcinomas in situ and in 20-30\% of infiltrating breast carcinomas $[31,32]$. The HER-2 status can be determined in human tumor samples using $\mathrm{IHC}$ or fluorescence in situ hybridization [32]. Amplification and/or overexpression of the HER-2 oncogene is associated with a poor DFS rate in patients with axillary node-positive breast cancer [32-34].

Allred and colleagues [35] evaluated HER-2 expression using IHC in 613 patients with node-negative breast cancer enrolled in the Intergroup Study 0011. In their study, patients were stratified into low-risk groups $(n=307)$ and high-risk groups $(n=306)$ on the basis of tumor size and ER status. Low-risk patients were defined as having small $(<3 \mathrm{~cm})$, ER-positive tumors and were observed without additional treatment after initial surgery. High-risk patients had either ER-negative tumors or large $(\geq 3 \mathrm{~cm})$, ER-positive tumors and were randomized to be observed $(n=146)$ or to receive adjuvant chemotherapy ( $n=160)$ after surgery. In Allred and colleagues' study, HER-2 was overexpressed in $14.3 \%$ of all tumors combined, and overexpression was higher in invasive carcinomas associated with an extensive in situ component $(21.5 \%)$ than in carcinomas without a significant noninvasive or in situ histologic component (11.2\%; $P<0.0001)$. When patients with low-risk lesions not containing a significant in situ component $(n=179)$ were analyzed, HER-2 was a strong prognostic factor. Patients in this group with HER-2-positive tumors showed only $40 \%$ DFS at 5 years, compared with more than $80 \%$ in patients with HER-2-negative tumors $(P<0.0001)$.

HER-2 overexpression has been associated with improved response to doxorubicin-based chemotherapy [36-40]. HER-2 overexpression does not seem to predict response to taxane-based chemotherapy [41]. The association between HER-2 overexpression and response to hormonal therapy is controversial $[40,42,43]$. Osborne and colleagues [44] reported an association between the ER coactivator AIB1 (SRC-3) and tamoxifen resistance, particularly in patients with HER-2-positive tumors treated with tamoxifen.

One of the main reasons for the clinical utility of the tissue measurement of HER-2 is for selection of patients with invasive breast cancer for trastuzumab monoclonal antibody therapy (Herceptin ${ }^{\mathrm{TM}}$; Genentech, San Francisco, CA, USA). The pivotal clinical trials of trastuzumab were conducted in patients with metastatic breast cancer overexpressing HER-2. The HER-2 status was determined by IHC using two monoclonal antibodies: CB-11 and 4D5. The HER-2 expression was scored as $0,1+, 2+$, and $3+$, depending on the number of cells with membrane staining and on the intensity of the staining. If the tumor 
was 0 or $1+$, it was considered HER-2-negative. If the tumor was $2+$ or $3+$ it was considered HER-2-positive, and patients received trastuzumab therapy. Retrospective studies showed that the response rate for trastuzumab therapy was higher among patients with an $\mathrm{IHC}$ score of $3+$ expression compared with patients having a score of $2+$. Good correlation was noted between a $3+$ score using $\mathrm{IHC}$ and the presence of HER-2 gene amplification using fluorescence in situ hybrization. Recent data indicate that fluorescence in situ hybrization may be a better predictor of response to trastuzumab-based therapy $[45,46]$. Trastuzumab is currently approved for treating patients with metastatic breast cancer. Adjuvant trials are ongoing to determine the safety and efficacy of trastuzumab in patients with early-stage breast cancer.

\section{Plasminogen activators and inhibitors}

Tumor cell invasion and metastasis is a multifactorial process that at each step may require the action of proteolytic enzymes, such as collagenases, cathepsins, plasmin, or plasminogen activators. Some of these molecules have been associated with specific prognoses and are now discussed in more detail.

The urokinase-type plasminogen activator (uPA) is a serine protease that plays an important role in the invasion and metastasis process through degradation of the extracellular matrix. High levels of tissue uPA and its inhibitors (plasminogen activator inhibitor [PAl]-1, PAl-2) measured using ELISAs have been correlated with poor outcome in node-negative breast cancer patients [47-51].

Janicke and colleagues [52] conducted a prospective, randomized multicenter clinical trial of adjuvant therapy versus observation for patients with node-negative breast cancer. In their study, patients whose primary tumors had low tumor levels of UPA and PAl-1 (low risk) did not receive adjuvant systemic therapy. Patients with elevated tumor levels of uPA and/or of PAl-1 (high risk) were randomized to receive cyclophosphamide, methotrexate, and 5-fluorouracil adjuvant chemotherapy or to receive no treatment. The first interim analysis showed an estimated 3 -year recurrence rate of $6.7 \%$ in the low-risk group and of $14.7 \%$ in the high-risk group $(P=0.006)$. The intent-totreat 3-year DFS rate for patients in the high-risk group assigned to chemotherapy or to observation was not statistically different. When the results were analyzed based on actual treatment delivered, however, the 3-year DFS rate for patients treated with adjuvant chemotherapy was $9 \%$ versus $19 \%$ for patients who did not receive chemotherapy $(P=0.016)$. The improvement in actuarial 3-year DFS was maintained at a median follow-up of 50 months [53].

Zemzoum and colleagues [54] showed that uPA/PAl-1
Table 2

Pro-angiogenic and anti-angiogenic proteins

\begin{tabular}{ll} 
Pro-angiogenic protein & Anti-angiogenic protein \\
\hline Vascular endothelial growth factor & Angiostatin \\
Angiogenin & Endostatin \\
Angiopoetin-1 & Interferon (alpha, beta) \\
Del-1 & Interleukin-12 \\
Fibroblast growth factors & 2-Methoxyestradiol \\
Follistatin & Platelet factor 4 \\
Interleukin-8 & Thrombospondin \\
Leptin & CD59 complement fragment \\
Placental growth factor & Heparinases \\
Platelet-derived endothelial & Tissue inhibitors of \\
growth factor & metalloproteinases \\
Pleiotrophin & Vasostatin \\
Transforming growth factor alpha & 16-kDa prolactin fragment \\
Transforming growth factor beta & \\
Tumor necrosis factor & \\
Vascular endothelial growth factor & \\
Hepatocyte growth factor & \\
Nitric oxide & \\
Erucamide & \\
Urokinase plasminogen activator & \\
\hline
\end{tabular}

aggressive course of disease in lymph node-negative breast cancer, independent of HER-2 status. It has been suggested that patients with node-negative breast cancer and low levels of UPA and PAI-1 may be spared the trauma of adjuvant chemotherapy [55]. However, the ELISAs of uPA/PAl-1 require extracts of primary tumor tissue, and this is a major limitation for patients with small tumors.

\section{Angiogenesis-related prognostic markers}

It is now accepted that solid tumors must develop a vascular network to grow beyond $1 \mathrm{~cm}^{3}$, and they do so by stimulating the formation of new blood vessels (socalled angiogenesis). Angiogenesis is an active process, regulated by a large number of pro-angiogenic and antiangiogenic molecules (Table 2). Interest in neovascularity as a prognostic factor was stimulated by the work of Folkman on tumor angiogenesis and by the potential for treatment with anti-angiogenic agents [56].

The prognostic relevance of tumor angiogenesis in breast cancer was first reported by Weidner and colleagues [57], who counted microvessels (veins and arteries) in the most densely vascularized areas of 49 invasive carcinomas and found their number and density significantly increased in 
cases with nodal and distant metastasis. In their study, the frequency of distant metastasis increased with an increase in the microvessel count. However, other studies showed conflicting results. Van Hoef and colleagues [58] reported considerable variability in the microvessel count in different parts of the same tumor and between the readings of two evaluators. These investigators found no significant correlation between microvessel count and other tumor factors of prognostic value, and found no significant correlation between the microvessel count and DFS. Until these issues are resolved, microvessel count should not be used routinely for making treatment decisions in breast cancer patients.

Angiogenic growth factors have been identified that may have important prognostic utility. These include the vascular endothelial growth factor, the platelet-derived endothelial cell growth factor (also known as thymidine phosphorylase), and the fibroblast growth factor family [59].

\section{Apoptosis-related prognostic markers}

Programmed cell death, also know as apoptosis, is an endogenous cellular process whereby an external signal activates a metabolic pathway that results in cell death (Table 3) [60]. This form of cell death is commonly seen in breast cancer tissue. Apoptotic cells can be quantitated by light microscopy, and an apoptotic index can be calculated. However, the prognostic significance of the apoptotic index is not well defined. Wu and colleagues [61] reported a correlation between a low apoptotic index and decreased patient survival. However, other studies found no correlation between apoptotic index and prognosis [62-64].

Bcl-2 is a mitochondrial protein known to inhibit apoptosis triggered by chemotherapy and radiation therapy. Lower levels of apoptosis could lead to malignant cell accumulation and therefore to a more aggressive clinical course for the disease. Although Bcl-2 can block apoptosis in vitro, several studies have shown that $\mathrm{Bcl}-2$ overexpression is associated with improved DFS rates [65]. This may be in part because of the close association between Bcl-2 expression and ER expression. Perhaps more important is the potential association between Bcl-2 expression and response to chemotherapy. Several studies have shown that patients with Bcl-2-negative breast cancer were more likely to respond to chemotherapy than patients with Bcl-2-positive tumors [66-68]. However, other studies found no association between $\mathrm{Bcl}-2$ expression and the response to chemotherapy $[69,70]$. Further studies are needed to establish the role of $\mathrm{Bcl}-2$ as a predictive factor of response to therapy.

\section{Genomics}

In addition to the markers already discussed, literally hundreds of other molecules have been evaluated as
Table 3

\begin{tabular}{ll} 
Members of the Bcl-2 family of apoptosis regulators \\
\hline Inhibitor of apoptosis & Promoter of apoptosis \\
\hline BCL-2 & BAX \\
BCL-X & BAK \\
MCL-1 & BOK \\
A-1/BFL-1 & BAD \\
BCL-W & BID \\
BOO/DIVA & BIK \\
NR-13 & BLK \\
& HRK \\
& BIM \\
& BNIP3 \\
& NIX \\
& NOXA \\
\hline
\end{tabular}

potential prognostic factors. Breast cancer is a complex heterogeneous disease, and therefore evaluation of a handful of genes and/or proteins provides only limited prognostic information. High-throughput gene expression profiling using microarray technology is a promising new technology that has been applied to the classification of breast cancers [71-73], to prognosis [74-77], and to prediction of response to treatment [78].

Using cDNA microarrays, Perou and colleagues [71] classified invasive breast carcinomas into five subtypes based on their distinct gene expression profile (Norway/ Stanford dataset). These included a luminal epithelial cell phenotype (subtypes $A$ and $B$ ), a basal epithelial cell type phenotype, a HER-2 (+) phenotype, and a group of cancers expressing a 'normal-like' gene profile. Sorlie and colleagues [79] showed that patients whose tumors exhibited the basal-like and HER-2-positive subtypes had the worst survival rates, while the luminal epithelial type was associated with improved survival rates. Although initially the luminal subtype correlated with ER positivity, Sorlie and colleagues noted that the ER levels were not uniform among tumors classified as luminal or basal types.

van't Veer and colleagues [74] used a different microarray platform and identified a 'poor prognosis signature' that included 70 genes involved in regulation of the cell cycle, in invasion, in metastasis, and in angiogenesis. The 70gene prognostic profile was validated by the same investigators in 295 consecutive patients with primary breast cancer [75]. Among the 295 patients, 180 had a poor-prognosis signature and 115 had a good-prognosis signature; the mean overall 10-year survival rates were 
$54.6 \%$ and $94.5 \%$, respectively. At 10 years, the probability of remaining free of distant metastases was $50.6 \%$ in the group with a poor-prognosis signature and was $85.2 \%$ in the group with a good-prognosis signature. The estimated hazard ratio for distant metastases in the group with a poor-prognosis signature as compared with the group with the good-prognosis signature was 5.1 (95\% confidence interval, 2.9-9.0; $P<0.001$ ). This ratio remained significant when the groups were analyzed according to their lymph-node status. This prognostic signature had a strong independent value on multivariate analysis. Ongoing studies are validating these results in commercially available microarrays for potential clinical and diagnostic applications.

Sorlie and colleagues [80] reanalyzed their Norway/ Stanford dataset, including 84 tissue samples from their previously published work $[71,79]$ and 38 additional tumor samples from patients with locally advanced breast cancer treated with preoperative chemotherapy. The first gene list and the list used for the reanalyzed report had approximately 200 genes in common, and tumors could be classified in the five main gene clusters as previously described. In addition, Sorlier and colleagues attempted to validate their findings in two independent datasets reported by Van't Veer and colleagues [75] and by West and colleagues [81]. Ninety-seven tumors from the van't Veer and colleagues' study could be classified into the five subtypes, and these different breast cancer types were associated with prognosis. Patients with the luminal-A subtype had the best survival rates, while the worst survival rates were associated with the basal and HER-2 subtypes. However, van't Veer and colleagues based their analysis on 461 genes (out of 24,480). The dataset from West and colleagues, generated on an Affymetrix platform, could also be classified into the previously described subtypes after selecting 242 genes out of a total of 7129 genes.

One of the main shortcomings of microarray technology is the lack of validation of gene sets across platforms. For example, when Sorlie and colleagues [80] tested the prognostic impact of the 231 markers published by van't Veer and colleagues on the Norwegian cohort, the positive predictive value for DFS was only $47 \%$. This may in part be due to the different patient cohorts and treatments. In fact, the differences in outcomes across studies are based on the subset of genes that was analyzed in all the studies, and the number of genes held in common across studies is limited.

Clinical trials are evaluating the prognostic and predictive value of gene expression profiles in patients with earlystage breast cancer. Chang and colleagues [82] evaluated gene expression profiles in tumors from 24 patients biopsies were obtained prior to initiation of chemotherapy, and cDNA analysis of RNA extracted from biopsy samples was completed using the HgU95-Av2 GeneChip (Affymetrix, Santa Clara, CA, USA). Differential patterns of expression of 92 genes correlated with docetaxel response $(P=0.001)$. Symmans and colleagues [83] showed that fine-needle aspiration yielded sufficient RNA for gene expression profiling. Since most breast cancer in patients is diagnosed at an early stage, the fine-needle aspiration approach may become acknowledged as the optimal way to obtain tissue for gene profiling. Pusztai and colleagues [78] extracted RNA from fine-needle aspiration specimens and identified a group of genes that predicted pathologic complete response to neoadjuvant chemotherapy.

Transcriptional profiling could until recently only be completed using fresh or frozen tissue, not using tissue from paraffin blocks. To overcome this limitation, several groups are developing methods to extract RNA from formalin-fixed, paraffin-embedded tissue for genomics studies. Ma and colleagues [84] microdissected breast cancer cells from paraffin-embedded tumors and measured expression on more than 20,000 genes in cancer cells using an Affymetrix platform. The authors were able to correlate gene expression signatures with prognosis. This is a step forward, and these findings should be validated in groups of patients treated homogeneously or not treated with adjuvant systemic therapy at all.

Several groups are evaluating the prognostic and predictive value of a multigene RT-PCR assay using paraffin-embedded tissue (Oncotype DX ${ }^{\text {TM}}$; Genomic Health, Redwood City, CA, USA). Sixteen genes had significant prognostic value in three preliminary studies that included patients with early-stage breast cancer treated with adjuvant tamoxifen and/or chemotherapy [85-87]. Five genes were added as reference genes, and a recurrence score was developed. Paik and colleagues [85] showed that the multigene RT-PCR assay had a strong predictive value in patients with a history of nodenegative, ER-positive tumors treated with tamoxifen in the adjuvant setting. The 10-year distant recurrence rate was $6.8 \%$ for patients with a low recurrence score, was $14.3 \%$ for patients with an intermediate recurrence score, and was $30.5 \%$ for patients with a high recurrence score.

A smaller study conducted at MD Anderson Cancer Center showed no relationship between OncotypeDX's recurrence score and distant recurrence-free survival in patients with node-negative breast cancer who had not received any adjuvant systemic therapy [88]. Although there may be many explanations for this finding, it is also possible that the model is good at predicting response or lack of response to tamoxifen but has limited prognostic power. More studies are needed to establish the prognostic role of this assay in clinical management. 


\section{Proteomics}

In the postgenome era, scientists have turned to proteomics to understand complex biological systems. Proteomics is defined as the identification, characterization, and quantification of all proteins involved in a particular tissue, organ, or organism to provide accurate and comprehensive data about that system.

One of the methods most commonly used to study differences in protein expression between two samples (e.g. cancer and normal tissue) is two-dimensional gel electrophoresis. Highly sensitive mass spectrometry methods are currently being used together to identify greater numbers of lower abundance proteins that are differentially expressed in defined cell populations. Matrixassisted laser desorption/ionization time-of-flight and surface-enhanced laser desorption/ionization time-of-flight analyses enable high-throughput characterization of lysates from even a very few tumor cells, and they may be best suited for clinical biomarker studies $[89,90]$.

Novel technologies still in developmental phases will enable identification of validated targets in small biopsy specimens, including high-density protein, antibody, and lysate arrays [91,92]. No proteomics-based assay for assessing prognosis in breast cancer patients has yet been developed.

\section{Conclusion}

Prognostic and predictive molecular markers commonly used in clinical practice include Ki-67, ER, PR, and HER-2. From the National Institute of Health overview it was clear that, once basic pathology had been excluded, there was very little else that had been appropriately validated and in which there was good quality control. This issue of quality control is one of the most important challenges for validation of most molecular markers discussed.

Prognostic indices that integrate clinical, histologic, and molecular parameters will need to be developed and validated in conjunction with novel bioinformatic methodologies (i.e. artificial intelligence) to aid clinical decisionmaking. High-throughput cDNA microarray technologies and tumor array technologies are allowing the expression of literally thousands of genes and proteins to be analyzed at one time. Validation of these technologies in adequately powered prospective clinical trials will allow the integration of multiple molecular factors in the risk assessment and management of individual patients with breast cancer.

\section{Competing interests}

None declared.

\section{Acknowledgements}

This work was supported in part by the Nellie B Connally Breast Cancer Research Fund, and by grants from the National Cancer Institute (CA82119) and the Department of Defense (DAMD17-03-10429). The authors thank Rachel E Williams for editorial assistance.

\section{References}

1. Early Breast Cancer Trialists' Collaborative Group: Systemic treatment of early breast cancer by hormonal, cytotoxic, or immune therapy. 133 randomised trials involving 31,000 recurrences and 24,000 deaths among 75,000 women. Lancet 1992, 339:1-15.

2. Early Breast Cancer Trialists' Collaborative Group: Tamoxifen for early breast cancer: an overview of the randomised trials. Lancet 1998, 351:1451-1467.

3. Eifel P, Axelson JA, Costa J, Crowley J, Curran WJJ, Deshler A, Fulton S, Hendricks CB, Kemeny M, Kornblith AB, Louis TA, Markman M, Mayer R, Roter D: National Institutes of Health Consensus Development Conference statement: adjuvant therapy for breast cancer, November 1-3, 2000. J Natl Cancer Inst 2001, 93:979-989.

4. Clark GM, Dressler LG, Owens MA, Pounds G, Oldaker T, McGuire WL: Prediction of relapse or survival in patients with node-negative breast cancer by DNA flow cytometry. $N$ Engl J Med 1989, 320:627-633.

5. Sahin AA, Ro J, Ro JY, Blick MB, el-Naggar AK, Ordonez NG, Fritsche HA, Smith TL, Hortobagyi GN, Ayala AG: Ki-67 immunostaining in node-negative stage I/II breast carcinoma. Significant correlation with prognosis. Cancer 1991, 68:549-557.

6. Keshgegian AA, Cnaan A: Proliferation markers in breast carcinoma. Mitotic figure count, S-phase fraction, proliferating cell nuclear antigen, Ki-67 and MIB-1. Am J Clin Pathol 1995, 104: 42-49.

7. Veronese SM, Gambacorta M, Gottardi O, Scanzi F, Ferrari M, Lampertico P: Proliferation index as a prognostic marker in breast cancer. Cancer 1993, 71:3926-3931.

8. Zhu X, Mancini MA, Chang KH, Liu CY, Chen CF, Shan B, Jones D, Yang-Feng TL, Lee WH: Characterization of a novel 350kilodalton nuclear phosphoprotein that is specifically involved in mitotic-phase progression. Mol Cell Biol 1995, 15:50175029.

9. Clark GM, Allred DC, Hilsenbeck SG, Chamness GC, Osborne $\mathrm{CK}$, Jones D, Lee WH: Mitosin (a new proliferation marker) correlates with clinical outcome in node-negative breast cancer. Cancer Res 1997, 57:5505-5508.

10. Sommer S, Fuqua SA: Estrogen receptor and breast cancer. Semin Cancer Biol 2001, 11:339-352.

11. Kuiper GG, Enmark E, Pelto-Huikko M, Nilsson S, Gustafsson JA: Cloning of a novel receptor expressed in rat prostate and ovary. Proc Natl Acad Sci USA 1996, 93:5925-5930.

12. Speirs V, Kerin MJ: Prognostic significance of oestrogen receptor beta in breast cancer. Br J Surg 2000, 87:405-409.

13. Dotzlaw H, Leygue E, Watson PH, Murphy LC: Estrogen receptor-beta messenger RNA expression in human breast tumor biopsies: relationship to steroid receptor status and regulation by progestins. Cancer Res 1999, 59:529-532.

14. Fuqua SA, Schiff R, Parra I, Friedrichs WE, Su JL, McKee DD, Slentz-Kesler K, Moore LB, Willson TM, Moore JT: Expression of wild-type estrogen receptor beta and variant isoforms in human breast cancer. Cancer Res 1999, 59:5425-5428.

15. Su JL, McKee DD, Ellis B, Kadwell SH, Wisely GB, Moore LB, Triantafillou JA, Kost TA, Fuqua S, Moore JT: Production and characterization of an estrogen receptor beta subtypespecific mouse monoclonal antibody. Hybridoma 2000, 19: 481-487.

16. Holmes FA, Fritsche HA, Loewy JW, Geitner AM, Sutton RC, Buzdar AU, Hortobagyi GN: Measurement of estrogen and progesterone receptors in human breast tumors: enzyme immunoassay versus binding assay. J Clin Oncol 1990, 8: 1025-1035.

17. Donegan WL: Tumor-related prognostic factors for breast cancer. CA Cancer J Clin 1997, 47:28-51.

18. Shek LL, Godolphin W: Survival with breast cancer: the importance of estrogen receptor quantity. Eur J Cancer Clin Oncol 1989, 25:243-250.

19. Hahnel R, Woodings T, Vivian AB: Prognostic value of estrogen receptors in primary breast cancer. Cancer 1979, 44:671-675.

20. Thorpe SM, Rose C, Rasmussen BB, King WJ, DeSombre ER, Blough RM, Mouridsen HT, Rossing N, Andersen KW: Steroid hormone receptors as prognostic indicators in primary breast cancer. Breast Cancer Res Treat 1986, 7:91-98.

21. Crowe JP, Jr, Gordon NH, Hubay CA, Shenk RR, Zollinger RM, Brumberg DJ, McGuire WL, Shuck JM: Estrogen receptor deter- 
mination and long term survival of patients with carcinoma of the breast. Surg Gynecol Obstet 1991, 173:273-278.

22. McGuire WL, Tandon AK, Allred DC, Chamness GC, Clark GM: How to use prognostic factors in axillary node-negative breast cancer patients. J Natl Cancer Inst 1990, 82:1006-1015.

23. Fisher B, Fisher ER, Redmond C, Brown A: Tumor nuclear grade, estrogen receptor, and progesterone receptor: their value alone or in combination as indicators of outcome following adjuvant therapy for breast cancer. Breast Cancer Res Treat 1986, 7:147-160.

24. Allred DC, Bryant J, Land S, Paik S, Fisher E, Julian T, Margolese $\mathrm{R}$, Smith R, Mamounas T, Osborne CK, Fisher B, Wolmark N: Estrogen receptor expression as a predictive marker of the effectiveness of tamoxifen in the treatment of DCIS: findings from NSABP Protocol B-24 [abstract]. Breast Cancer Res Treat 2002, 76:A36.

25. Fuqua SA, Schiff R, Parra I, Moore JT, Mohsin SK, Osborne CK, Clark GM, Allred DC: Estrogen receptor beta protein in human breast cancer: correlation with clinical tumor parameters. Cancer Res 2003, 63:2434-2439.

26. Dickson RB, Lippman ME: Growth factors in breast cancer. Endocr Rev 1995, 16:559-589.

27. Bacus SS, Gudkov AV, Esteva FJ, Yarden Y: Expression of erb$B$ receptors and their ligands in breast cancer: implications to biological behavior and therapeutic response. Breast Dis 2000, 11:63-75

28. Di Fiore PP, Pierce JH, Kraus MH, Segatto O, King CR, Aaronson SA: ErbB-2 is a potent oncogene when overexpressed in NIH/ 3T3 cells. Science 1987, 237:178-182.

29. Guy CT, Webster MA, Schaller M, Parsons TJ, Cardiff RD, Muller WJ: Expression of the neu protooncogene in the mammary epithelium of transgenic mice induces metastatic disease. Proc Natl Acad Sci USA 1992, 89:10578-10582.

30. Esteva-Lorenzo FJ, Sastry L, King CR: The erbB-2 gene: from research to application. In Hormones and Growth Factors in Development and Neoplasia. Edited by Dickson RB, Salomon DS. New York: John Wiley \& Sons; 1998:421-444.

31. King CR, Kraus MH, Williams LT, Merlino GT, Pastan IH, Aaronson SA: Human tumor cell lines with EGF receptor gene amplification in the absence of aberrant sized mRNAs. Nucleic Acids Res 1985, 13:8477-8486.

32. Slamon DJ, Clark GM, Wong SG, Levin WJ, Ullrich A, McGuire WL: Human breast cancer: correlation of relapse and survival with amplification of the HER-2/neu oncogene. Science 1987, 235:177-182.

33. Esteva FJ, Pusztai L, Symmans WF, Sneige N, Hortobagi GN: Clinical relevance of HER-2 amplification and overexpression in human cancers. Ref Gynecol Obst 2000, 7:267-276.

34. Borg A, Tandon AK, Sigurdsson H, Clark GM, Ferno M, Fuqua SA, Killander D, McGuire WL: HER-2/neu amplification predicts poor survival in node-positive breast cancer. Cancer Res 1990, 50:4332-4337.

35. Allred DC, Clark GM, Tandon AK, Molina R, Tormey DC, Osborne CK, Gilchrist KW, Mansour EG, Abeloff M, Eudey L, et al.: Her$2 /$ neu in node-negative breast cancer: prognostic significance of overexpression influenced by the presence of in situ carcinoma. J Clin Oncol 1992, 10:599-605.

36. Wood WC, Budman DR, Korzun AH, Cooper MR, Younger J, Hart RD, Moore A, Ellerton JA, Norton L, Ferree CR: Dose and dose intensity of adjuvant chemotherapy for stage II, node-positive breast carcinoma. N Engl J Med 1994, 330:1253-1259.

37. Muss HB, Thor AD, Berry DA, Kute T, Liu ET, Koerner F, Cirrincione CT, Budman DR, Wood WC, Barcos M, Henderson IC: c-erbB-2 expression and response to adjuvant therapy in women with node-positive early breast cancer. $N$ Engl J Med 1994, 330:1260-1266.

38. Thor AD, Berry DA, Budman DR, Muss HB, Kute T, Henderson IC, Barcos M, Cirrincione C, Edgerton S, Allred C, Norton L, Liu ET: erbB-2, p53, and efficacy of adjuvant therapy in lymph nodepositive breast cancer. J Natl Cancer Inst 1998, 90:1346-1360.

39. Paik S, Bryant J, Park C, Fisher B, Tan-Chiu E, Hyams D, Fisher ER, Lippman ME, Wickerham DL, Wolmark N: erbB-2 and response to doxorubicin in patients with axillary lymph nodepositive, hormone receptor-negative breast cancer. J Natl Cancer Inst 1998, 90:1361-1370.

40. Ravdin PM, Green S, Albain KS, Boucher V, Ingle J, Pritchard K, Shepard L, Davidson N, Hayes DF, Clark GM, Martino S, Osborne
CK, Allred DC: Initial report of the SWOG biological correlative study of C-erbB-2 expression as a predictor of outcome in a trial comparing adjuvant CAF $T$ with tamoxifen $(T)$ alone [abstract]. Proc Am Soc Clin Oncol 1998, 17:A374.

41. Van Poznak C, Tan L, Panageas KS, Arroyo CD, Hudis C, Norton L, Seidman AD: Assessment of molecular markers of clinical sensitivity to single-agent taxane therapy for metastatic breast cancer. J Clin Oncol 2002, 20:2319-2326.

42. De Placido S, De Laurentiis M, Carlomagno C, Gallo C, Perrone F, Pepe S, Ruggiero A, Marinelli A, Pagliarulo C, Panico L, Pettinato $G$, Petrella $G$, Bianco AR: Twenty-year results of the Naples GUN randomized trial: Predictive factors of adjuvant tamoxifen efficacy in early breast cancer. Clin Cancer Res 2003, 9:1039-1046.

43. Elledge RM, Green S, Ciocca D, Pugh R, Allred DC, Clark GM, Hill J, Ravdin P, O'Sullivan J, Martino S, Osborne CK: HER-2 expression and response to tamoxifen in estrogen receptorpositive breast cancer: a Southwest Oncology Group Study. Clin Cancer Res 1998, 4:7-12.

44. Osborne CK, Bardou V, Hopp TA, Chamness GC, Hilsenbeck SG, Fuqua SA, Wong J, Allred DC, Clark GM, Schiff R: Role of the estrogen receptor coactivator AIB1 (SRC-3) and HER-2/ neu in tamoxifen resistance in breast cancer. J Natl Cancer Inst 2003, 95:353-361.

45. Press M, Anderson S, Dybdal N, Lieberman G, Mass R: Fluorescence in situ hybridization (FISH) is superior to immunohistochemistry (IHC) for determining HER2 status: the Herceptin (R) experience [abstract]. Mod Patho/ 2002, 15:A47.

46. Seidman AD, Fornier M, Esteva FJ, Tan L, Kaptain S, Bach A, Panageas KS, Arroyo C, Valero V, Currie V, Gilewski T, Theodoulou M, Moynahan ME, Moasser M, Sklarin N, Dickler M, D'Andrea G, Cristofanilli M, Rivera E, Hortobagyi GN, Norton L, Hudis C: Weekly trastuzumab and paclitaxel therapy for metastatic breast cancer with analysis of efficacy by HER2 immunophenotype and gene amplification. J Clin Oncol 2001, 19:2587-2595.

47. Janicke F, Schmitt $M$, Pache L, Ulm K, Harbeck N, Hofler $H$, Graeff $\mathrm{H}$ : Urokinase (UPA) and its inhibitor PAI-1 are strong and independent prognostic factors in node-negative breast cancer. Breast Cancer Res Treat 1993, 24:195-208.

48. Bouchet C, Spyratos F, Martin PM, Hacene K, Gentile A, Oglobine J: Prognostic value of urokinase-type plasminogen activator (UPA) and plasminogen activator inhibitors PAl-1 and PAI-2 in breast carcinomas. Br J Cancer 1994, 69:398-405.

49. Grondahl-Hansen J, Hilsenbeck SG, Christensen IJ, Clark GM, Osborne CK, Brunner N: Prognostic significance of PAI-1 and uPA in cytosolic extracts obtained from node-positive breast cancer patients. Breast Cancer Res Treat 1997, 43:153-163.

50. Broet P, Spyratos F, Romain S, Quillien V, Daver A, Ricolleau G, Rallet A, Toulas C, Asselain B: Prognostic value of uPA and p53 accumulation measured by quantitative biochemical assays in 1245 primary breast cancer patients: a multicentre study. $\mathrm{Br} J$ Cancer 1999, 80:536-545.

51. de Witte JH, Sweep CG, Klijn JG, Grebenschikov N, Peters HA, Look MP, van Tienoven TH, Heuvel JJ, van Putten WL, Benraad TJ, Foekens JA: Prognostic impact of urokinase-type plasminogen activator (UPA) and its inhibitor (PAl-1) in cytosols and pellet extracts derived from 892 breast cancer patients. $\mathrm{Br} J$ Cancer 1999, 79:1190-1198.

52. Janicke F, Prechtl A, Thomssen C, Harbeck N, Meisner C, Untch M, Sweep CGJF, Selbmann HK, Graeff H, Schmitt M: Randomized adjuvant chemotherapy trial in high-risk, lymph nodenegative breast cancer patients identified by urokinase-type plasminogen activator and plasminogen activator inhibitor type 1. J Natl Cancer Inst 2001, 93:913-920.

53. Harbeck N, Meisner C, Prechtl A, Untch M, Selbmann HK, Sweep F, Graeff H, Schmitt M, Jaenicke F, Thomssen C: Level-I evidence for prognostic and predictive impact of UPA and PAI-1 in node-negative breast cancer provided by second scheduled analysis of multicenter Chemo- $\mathrm{N}-\mathrm{O}$ therapy trial [abstract]. Breast Cancer Res Treat 2001, 89:A213.

54. Zemzoum I, Kates RE, Ross JS, Dettmar P, Dutta M, Henrichs C Yurdseven S, Hofler $H$, Kiechle M, Schmitt M, Harbeck N: Invasion factors UPA/PAI-1 and HER2 status provide independent and complementary information on patient outcome in node-negative breast cancer. J Clin Oncol 2003, 21:10221028. 
55. Harbeck N, Schmitt M, Kates RE, Kiechle M, Zemzoum I, Janicke $\mathrm{F}$, Thomssen C: Clinical utility of urokinase-type plasminogen activator and plasminogen activator inhibitor-1 determination in primary breast cancer tissue for individualized therapy concepts. Clin Breast Cancer 2002, 3:196-200.

56. Folkman J: Angiogenesis in cancer, vascular, rheumatoid and other disease. Nat Med 1995, 1:27-31.

57. Weidner N, Semple JP, Welch WR, Folkman J: Tumor angiogenesis and metastasis-correlation in invasive breast carcinoma. $N$ Engl J Med 1991, 324:1-8.

58. Van Hoef ME, Knox WF, Dhesi SS, Howell A, Schor AM: Assessment of tumour vascularity as a prognostic factor in lymph node negative invasive breast cancer. Eur J Cancer 1993, 29A: 1141-1145.

59. Gasparini G: Clinical significance of determination of surrogate markers of angiogenesis in breast cancer. Crit Rev Oncol Hematol 2001, 37:97-114.

60. Wyllie AH, Kerr JF, Currie AR: Cell death: the significance of apoptosis. Int Rev Cytol 1980, 68:251-306.

61. Wu J, Shen ZZ, Lu JS, Jiang M, Han QX, Fontana JA, Barsky SH, Shao ZM: Prognostic role of p27Kip1 and apoptosis in human breast cancer. Br J Cancer 1999, 79:1572-1578.

62. Lipponen P, Aaltomaa S, Kosma VM, Syrjanen K: Apoptosis in breast cancer as related to histopathological characteristics and prognosis. Eur J Cancer 1994, 30A:2068-2073.

63. Zhang GJ, Kimijima I, Abe R, Watanabe T, Kanno M, Hara K, Tsuchiya A: Apoptotic index correlates to bcl-2 and p53 protein expression, histological grade and prognosis in invasive breast cancers. Anticancer Res 1998, 18:1989-1998.

64. Liu SQ, Edgerton SM, Moore DHI, Thor AD: Measures of cell turnover (proliferation and apoptosis) and their association with survival in breast cancer. Clin Cancer Res 2001, 7:1716-1723.

65. Gasparini G, Barbareschi M, Doglioni C, Palma PD, Mauri FA, Boracchi P, Bevilacqua P, Caffo O, Morelli L, Verderio P: Expression of bcl-2 protein predicts efficacy of adjuvant treatments in operable node-positive breast cancer. Clin Cancer Res 1995, 1:189-198.

66. Bonetti A, Zaninelli M, Leone R, Cetto GL, Pelosi G, Biolo S, Menghi A, Manfrin E, Bonetti F, Piubello Q: bcl-2 but not p53 expression is associated with resistance to chemotherapy in advanced breast cancer. Clin Cancer Res 1998, 4:2331-2336.

67. Pusztai L, Krishnamurthy S, Perez-Cardona J, Sneige N, Esteva FJ, Volchenok M, Breitenfelder P, Kau SW, Takayama S, Krajewski S, Reed JC, Hortobagyi GN, Bast RC: Expression of BAG-1 and BCL-2 proteins before and after neoadjuvant chemotherapy of locally advanced breast cancer. Cancer Invest 2004, in press.

68. Buchholz TA, Davis DW, McConkey DJ, Symmans WF, Valero V, Jhingran A, Tucker SL, Pusztai L, Cristofanilli M, Esteva FJ, Hortobagyi GN, Sahin AA: Chemotherapy-induced apoptosis and $\mathrm{Bcl}-2$ levels correlate with breast cancer response to chemotherapy. Cancer J 2003, 9:33-41.

69. Bottini A, Berruti A, Bersiga A, Brizzi MP, Brunelli A, Gorzegno G, DiMarco B, Aguggini S, Bolsi G, Cirillo F, Filippini L, Betri E, Bertoli G, Alquati P, Dogliotti L: p53 but not bcl-2 immunostaining is predictive of poor clinical complete response to primary chemotherapy in breast cancer patients. Clin Cancer Res 2000, 6:2751-2758.

70. Poelman SM, Adeyanju MO, Robertson MA, Recant WM, Karrison T, Fleming GF, Olopade OI, Conzen SD: Human breast cancer susceptibility to paclitaxel therapy is independent of $\mathrm{Bcl}-2$ expression. Clin Cancer Res 2000, 6:4043-4048.

71. Perou CM, Sorlie T, Eisen MB, van de RM, Jeffrey SS, Rees CA, Pollack JR, Ross DT, Johnsen H, Akslen LA, Fluge O, Pergamenschikov A, Williams C, Zhu SX, Lonning PE, Borresen-Dale AL, Brown PO, Botstein D: Molecular portraits of human breast tumours. Nature 2000, 406:747-752.

72. Pusztai L, Ayers M, Stec J, Clark E, Hess K, Stivers D, Damokosh A, Sneige N, Buchholz TA, Esteva FJ, Arun B, Cristofanilli M, Booser D, Rosales M, Valero V, Adams C, Hortobagyi GN, Symmans WF: Gene expression profiles obtained from fineneedle aspirations of breast cancer reliably identify routine prognostic markers and reveal large-scale molecular differences between estrogen-negative and estrogen-positive tumors. Clin Cancer Res 2003, 9:2406-2415.

73. Pusztai L, Sotiriou C, Buchholz TA, Meric F, Symmans WF, Esteva FJ, Sahin A, Liu ET, Hortobagi GN: Molecular profiles of inva- sive mucinous and ductal carcinomas of the breast: a molecular case study. Cancer Genet Cytogenet 2003, 141:148-153.

74. van't Veer $L$, Dai $H$, van de Vijver MJ, He YD, Hart AA, Mao M, Peterse HL, van der KK, Marton MJ, Witteveen AT, Schreiber GJ, Kerkhoven RM, Roberts C, Linsley PS, Bernards R, Friend SH: Gene expression profiling predicts clinical outcome of breast cancer. Nature 2002, 415:530-536.

75. van de Vijver MJ, He YD, van't Veer LJ, Dai H, Hart AA, Voskuil DW, Schreiber GJ, Peterse JL, Roberts C, Marton MJ, Parrish M, Atsma D, Witteveen A, Glas A, Delahaye L, van der Velde, Bartelink H, Rodenhuis S, Rutgers ET, Friend SH, Bernards R: A gene-expression signature as a predictor of survival in breast cancer. N Engl J Med 2002, 347:1999-2009.

76. Bertucci F, Houlgatte R, Granjeaud S, Nasser V, Loriod B, Beaudoing E, Hingamp P, Jacquemier J, Viens P, Birnbaum D, Nguyen C: Prognosis of breast cancer and gene expression profiling using DNA arrays. Ann NY Acad Sci 2002, 975:217-231.

77. Bertucci $F$, Nasser V, Granjeaud S, Eisinger F, Adelaide J, Tagett R, Loriod A, Giaconia A, Benziane A, Devilard E, Jacquemier J, Viens P, Nguyen C, Birnbaum D, Houlgatte M: Gene expression profiles of poor-prognosis primary breast cancer correlate with survival. Hum Mol Genet 2002, 11:863-872.

78. Pusztai L, Ayers M, Symmans WF, Damokosh A, Hess K, Valero V, Clark E, Ross J, Hortobagyi GN, Stec J: Emerging science: prospective validation of gene expression profiling-based prediction of complete pathologic response to neoadjuvant paclitaxel/FAC chemotherapy in breast cancer [abstract]. Proc Am Soc Clin Oncol 2003, 22:A1.

79. Sorlie T, Perou CM, Tibshirani R, Aas T, Geisler S, Johnsen H, Hastie T, Eisen MB, van de Rijn M, Jeffrey SS, Thorsen T, Quist H, Matese JC, Brown PO, Botstein D, Lonning PE, Borresen-Dale AL: Gene expression patterns of breast carcinomas distinguish tumor subclasses with clinical implications. Proc Nat/ Acad Sci USA 2001, 98:10869-10874.

80. Sorlie T, Tibshirani R, Parker J, Hastie T, Marron JS, Nobel A, Deng S, Johnsen H, Pesich R, Geisler S, Demeter J, Perou CM, Lonning PE, Brown PO, Borresen-Dale AL, Botstein D: Repeated observation of breast tumor subtypes in independent gene expression data sets. Proc Natl Acad Sci USA 2003, 100: 8418-8423.

81. West $M$, Blanchette $C$, Dressman $H$, Huang $E$, Ishida $S$, Spang $R$, Zuzan H, Olson JA, Jr, Marks JR, Nevins JR: Predicting the clinical status of human breast cancer by using gene expression profiles. Proc Natl Acad Sci USA 2001, 98:11462-11467.

82. Chang JC, Wooten EC, Tsimelzon A, Hilsenbeck SG, Gutierrez MC, Elledge R, Mohsin S, Osborne CK, Chamness GC, Allred DC, O'Connell P: Gene expression profiling for the prediction of therapeutic response to docetaxel in patients with breast cancer. Lancet 2003, 362:362-369.

83. Symmans WF, Ayers M, Clark EA, Stec J, Hess KR, Sneige N, Buchholz TA, Krishnamurthy S, Ibrahim NK, Buzdar AU, Theriault RL, Rosales MF, Thomas ES, Gwyn KM, Green MC, Syed AR, Hortobagyi GN, Pusztai L: Total RNA yield and microarray gene expression profiles from fine-needle aspiration biopsy and core-needle biopsy samples of breast carcinoma. Cancer 2003, 97:2960-2971.

84. Ma X-J, Wang W, Salunga R, Tuggle T, Stecker K, Baer TM, Erlander MG, Witliff JL: Gene expression signatures associated with clinical outcome in breast cancer via laser capture microdissection [abstract]. Breast Cancer Res Treat 2003, 82: A29.

85. Paik S, Shak S, Tang G, Kim C, Baker J, Cronin M, Baehner R, Walker M, Watson D, Park T, Bryant J, Wolmark N: Multi-gene RT-PCR assay for predicting recurrence in node negative breast cancer patients - NSABP studies B-20 and B-14 [abstract]. Breast Cancer Res Treat 2003, 82:A16

86. Cobleigh MA, Bitterman P, Baker J, Cronin M, Liu M-L, Borchik B, Tabesh B, Mosquera JM, Walker MG, Shak S: Tumor gene expression predicts distant disease-free survival (DDFS) in breast cancer patients with 10 or more positive nodes: high throughput RT-PCR assay of paraffin-embedded tumor tissues [abstract]. Proc Am Soc Clin Oncol 2003, 22:A3415.

87. Esteban J, Baker J, Cronin M, Liu M, Llamas MG, Walker MG, Mena R, Shak S: Tumor gene expression and prognosis in breast cancer: multi-gene RT-PCR assay of paraffin-embedded tissue [abstract]. Proc Am Soc Clin Oncol 2003, 22: A3416. 
88. Esteva FJ, Sahin AA, Coombes K, Baker J, Cronin M, Walker M, Watson D, Cristofanilli M, Shak S, Hortobagi GN: Multi-gene RTPCR assay for redicting recurrence in node negative breast cancer patients - M. D. Anderson Clinical Validation Study [abstract]. Breast Cancer Res Treat 2003, 82:A17.

89. Wulfkuhle JD, McLean KC, Paweletz CP, Sgroi DC, Trock BJ, Steeg PS, Petricoin EFI: New approaches to proteomic analysis of breast cancer. Proteomics 2001, 1:1205-1215.

90. Madoz-Gurpide J, Wang H, Misek DE, Brichory F, Hanash SM: Protein based microarrays: a tool for probing the proteome of cancer cells and tissues. Proteomics 2001, 1:1279-1287.

91. Liotta LA, Espina V, Mehta Al, Calvert V, Rosenblatt K, Geho D, Munson PJ, Young L, Wulfkuhle J, Petricoin EF, III: Protein microarrays: meeting analytical challenges for clinical applications. Cancer Cell 2003, 3:317-325.

92. Wulfkuhle JD, Liotta LA, Petricoin EF: Proteomic applications for the early detection of cancer. Nat Rev Cancer 2003, 3:267275 .

\section{Correspondence}

Francisco J Esteva, MD, PhD, Associate Professor of Medicine, Department of Breast Medical Oncology, Unit 424, The University of Texas MD Anderson Cancer Center, 1515 Holcombe Boulevard, Houston, TX 77030, USA. Tel: +1 713792 2817; fax: +1 713745 5768; e-mail: festeva@mdanderson.org 